\title{
Book Available for Review
}

The following books are available for review. Requests should be addressed to:

Book Review Editor, Auslegung

Philosophy Department

The University of Kansas

1445 Jayhawk Blvd, Rm 3090

Lawrence, KS 66045-7590

Allen, Colin and Michael Hand. Logic Primer. Cambridge, Massachusetts and London, England: MIT Press, 2001.

Allison, Henry E. Kant's Theory of Taste: A Reading of The Critique of Aesthetic Judgment. Cambridge: Cambridge University Press, 2001.

Baldwin, Thomas, ed. The Cambridge History of Philosophy 1870-1945. Cambridge: Cambridge University Press, 2004.

Berg, Manfred and Martin H. Geyer. Two Cultures of Rights:

The Quest for Inclusion and Participation in Modern America and Germany. Cambridge: Cambridge University Press, 2002.

Bernstein, J. M., ed. Classic and Romantic German Aesthetics. Cambridge: Cambridge University Press, 2003.

Broad, Jacqueline. Women Philosophers of the Seventeenth

Century. Cambridge: Cambridge University Press, 2002.

Broadie, Alexander. The Scottish Enlightenment. Cambridge:

Cambridge University Press, 2003.

Brook, Andrew and Don Ross, eds. Daniel Dennett. Cambridge:

Cambridge University Press, 2002.

Buzaglo, Meir. Solomon Maimon: Monism, Skepticism, and

Mathematics. Pittsburgh: University of Pittsburgh Press, 2002.

Cavendish, Margaret. Observations upon Experimental

Philosophy. Cambridge: Cambridge University Press, 2001. 
Cohen, I Bernard and George E. Smith. The Cambridge Companion to Newton. Cambridge: Cambridge University Press, 2002.

Cooper, William S. The Evolution of Reason: Logic as a Branch of Biology. Cambridge: Cambridge University Press, 2001.

Dahlstrom, Daniel O. Heidegger's Concept of Truth. Cambridge:

Cambridge University Press, 2001.

Dickerson, A. B. Kant on representation and objectivity. Cambridge: Cambridge University Press, 2004.

Doris, John M. Lack of Character: Personality \& Moral Behavior. Cambridge: Cambridge University Press, 2002.

Dostal, Robert J., ed. The Cambridge Companion to Gadamer.

Cambridge: Cambridge University Press, 2002.

Evans, J. Martin, ed. John Milton: Twentieth-Century

Perspectives Volume 4: Paradise Lost. New York and London: Routledge, 2003.

Faas, Ekbert. The Geneology of Aesthetics. Cambridge:

Cambridge University Press, 2002.

Foley, Richard. Intellectual Trust in Oneself and Others.

Cambridge: Cambridge University Press, 2001.

Galeotti, Anna Elisabetta. Toleration as Recognition.

Cambridge: Cambridge University Press, 2002.

Garber, Daniel. Descartes Embodied: Reading Cartesian Philosophy Through Cartesian Science. Cambridge: Cambridge University Press, 2001.

Gaukroger, Stephen. Descartes 'System of Natural Philosophy.

Cambridge: Cambridge University Press, 2001.

Gerwen, Rob van. Richard Wollheim on the Art of Painting. Cambridge: Cambridge University Press, 2001.

Glock, Hans-Johnson. Quine and Davidson on Language, Thought, and Reality. Cambridge: Cambridge University Press, 2003. 
Goldman, Alan H. Practical Rules: When We Need Them and When We Don't. Cambridge: Cambridge University Press, 2002.

Hammerstein, Kai. The German Aesthetic Tradition. Cambridge: Cambridge University Press, 2002.

Heidegger, Martin. Off the Beaten Track. Translated and edited by Julian Young and Kenneth Haynes. Cambridge:

Cambridge University Press, 2002.

Helm, Bennett W. Emotional Reason: Deliberation, Motivation, and the Nature of Value. Cambridge: Cambridge University Press, 2001.

Herder, Johann Gottfried von. Philosophical Writings.

Translated and edited by Michael N. Forster. Cambridge:

Cambridge University Press, 2002.

Howie, David. Interpreting Probability: Controversies and

Developments in the Early Twentieth Century. Cambridge:

Cambridge University Press, 2002.

Hunter, Ian. Rival Enlightenments: Civil and Metaphysical

Philosophy in Early Modern Germany. Cambridge:

Cambridge University Press, 2002.

Jacobs, Brian and Patrick Kain. Essays on Kants Anthropologl:

Cambridge: Cambridge University Press, 2003.

Jacquette, Dale, ed. The Cambridge Companion to Brentano.

Cambridge: Cambridge University Press, 2004.

Jha, Stefania Ruzsits. Reconsidering Michael Polany' $s$

Philosophy. Pittsburgh: University of Pittsburgh Press, 2002.

Joyce, Richard. The Myth of Morality. Cambridge: Cambridge

University Press, 2001.

Kaplan, David M. Ricoeur's Critical Theory. Albany: State University of New York Press, 2003.

Kerstein, Samuel J. Kant's Search for the Supreme Principle of Morality. Cambridge: Cambridge University Press, 2002. 
La Vopa, Anthony J. Fichte: The Self and the Calling of

Philosophy, 1762-1799. Cambridge: Cambridge University Press, 2001.

Mercer, Christia. Leibniz's Metaphysics: its Origin and

Development. Cambridge: Cambridge University Press, 2001.

Moore, Gregory. Nietzsche, Biology and Metaphor. Cambridge:

Cambridge University Press, 2002.

Nietzsche, Friedrich. Beyond Good and Evil. Translated by

Judith Norman. Edited by Rolf-Peter Horstmann.

Cambridge: Cambridge University Press, 2002.

Oliver, Phil. William James's Springs of Delight: The Return to Life. Nashville: Vanderbilt University Press, 2001.

Ostrow, Matthew B. Wittgenstein's Tractatus. Cambridge:

Cambridge University Press, 2002.

Ott, Walter. Locke's Philosophy of Language. Cambridge:

Cambridge University Press, 2004.

Pangle, Lorraine Smith. Aristotle and the Philosophy of

Friendship. Cambridge: Cambridge University Press, 2003.

Pasnau, Robert, ed. The Cambridge Translations of Medieval

Philosophical Texts Vol. III: Mind and Knowledge.

Cambridge: Cambridge University Press, 2002.

Perkins, Franlin. Liebniz and China A Commerce of Light.

Cambridge: Cambridge University Press, 2004.

Perry, John. Knowledge, Possibility, and Consciousness.

Cambridge, Massachusetts and London, England: MIT Press, 2001.

Pinkard, Terry. German Philosophy 1760-1860: The Legacy of Idealism. Cambridge: Cambridge University Press, 2002.

Rescher, Nicholas. Cognitive Pragmatism: The Theory of Knowledge in Pragmatic Perspective. Pittsburgh: University of Pittsburgh Press, 2001. 
Rescher, Nicholas. Theory \& Practice of Distributive Justice.

New Brunswick, New Jersey: Transaction Publishers, 2002.

Rescher, Nicholas. Minding Matter and Other Essays in

Philosophical Inquiry. New York: Rowan \& Littlefield

Publishers, 2001.

Rescher, Nicholas. Philosophical Reasoning: A Study in the Methodology of Philosophizing. Oxford: Blackwell Publishers, 2001.

Rowlands, Mark. The Nature of Consciousness. Cambridge:

Cambridge University Press, 2001.

Santayana, George. The Letters of George Santayana: Book One ([1866] B 1909). Cambridge, Massachusetts and London, England: MIT Press, 2001.

Saul, Nicholas. Philosophy and German Literature, 1700-1990.

Cambridge: Cambridge University Press, 2002.

Schleicrmacher, Friedrich. Lectures on Philosophical Ethics.

Translated by Louise Adey Huish. Edited by Robert B.

Louden. Cambridge: Cambridge University Press, 2002.

Schmaltz, Tad M. Radical Cartesianism: The French Reception

of Descartes. Cambridge: Cambridge University Press, 2002.

Schnecwing, J. B., ed. Moral Philosophy from Montaigne to

Kant. Cambridge: Cambridge University Press, 2003.

Sessions, William Lad. Reading Hume's Dialogues: $A$

Veneration for True Religion. Bloomington and Indianapolis: Indiana University Press, 2002.

Sherratt, Yvonne. Adorno's Positive Dialectic. Cambridge:

Cambridge University Press, 2002.Smith, Adam. The Theory of Moral Sentiments. Cambridge: Cambridge University Press, 2002.

Speight, Allen. Hegel, Literature and the Problem of Agency.

Cambridge: Cambridge University Press, 2001. 
Stamos, David N. The Species Problem: Biological Species, Ontology, and the Metaphysics of Biology. Oxford: Lexington Books, 2003.

Van Ingwagen, Peter. Ontology, identity, and modality: Essays in metaphysics. Cambridge: Cambridge University Press, 2001.

Vico. The First Science. Edited and translated by Leon Pompa. Cambridge: Cambridge University Press, 2002.

Wilson, Catherine. Descartes's Mediations an Introduction. Cambridge: Cambridge University Press, 2004.

Young, Julian. Heidegger 's Later Philosophy. Cambridge:

Cambridge University Press, 2002. 